\title{
Scheduling of UKM (Unit Kegiatan Mahasiswa) Sports Activities at State University of Medan (UNIMED) Using Genetic Algorithm
}

\author{
Yanty Faradillah \\ Faculty of Information System, Harapan University, Medan, Indonesia \\ suksesgroup57@yahoo.com
}

\begin{abstract}
Scheduling is a complex and time-consuming process, and there are many things to be adjusted. Therefore, the conventional scheduling can be completed by using the Genetic Algorithm method. This research is to solve the problem of scheduling on the activities of UKM (Unit Kegiatan Mahasiswa)//Student Activity Unit) Sport at Unimed, by using the search technique simultaneously on a number of solutions that might be known as population term. Individuals which exist in one individual population contained in one population are called chromosomes. This chromosome is a solution that is still a symbol. The initial population is randomly constructed, while the population is the result of the evolution of chromosomes through literacy called generation. Using this Genetic Algorithm scheduling plan would bring benefits to the user because scheduling can be seen on the computer and in preparing of the next schedule, there won't be a problem or conflict.
\end{abstract}

Index Terms— Scheduling, Genetic Algorithm

\section{INTRODUCTION}

The development of Information Technology is growing very rapidly so it is very helpful personal or company to perform a scheduling process which can conventionally use a genetic algorithm in Sport UKM at Unimed in applying scheduling tournaments or sport events conducted by a group of students' room the university itself as well as with students from other universities.

UKM Sport Unimed is an organization which has many activities both inside and outside campus, often organizers of this organization confused in preparing a schedule of matches or exercise schedule because the activities of this organization is very solid and during this time there are many schedules that clashed. In adjusting the schedule of activities with the instructor's schedule became a problem because it is not in accordance with the instructor's schedule, and Instructors often got their schedule clashing with other activities. So the preparation of the activity schedule is still using a manual way, with graffiti on paper.

To facilitate the scheduling process, te researchers proposed a genetic algorithm as a method to find the best and effective solution of the problem of scheduling activities related to the readiness of the instructor.

Based on the above description, the researcher was interested in raising this issue "Scheduling UKM (Unit Kegiatan Mahasiswa) Sport Activities at State University of Medan (Unimed) using Genetic Algorithm".

\section{RESEARCH METHODS}

The first time the genetic algorithm was introduced by John Holland in 1975 from the University of Michigan, John Holland says that any problem in the form of adaptation (natural or artificial) can be formulated into terminology genetics (Arhami, 2011).

Aside from that Genetic Algorithm has characteristics that need to be known so that it can be distinguished from the search procedure or other optimization that is:

1.The Genetic Algorithm works by coding of the problem solution set based on predefined parameters and not the parameter it self

2. The Genetic Algorithm searches a population of a number of individuals who are the solution to problems not just of an individual.

3. Genetic Algorithm is the information of objective function (fitness), as a way to evaluate the individual who has the best solution, not the derivative of a function.

4. The Genetic Algorithm uses the rules of opportunity transition, and it is not as the deterministic rules.

In this algorithm, the search technique is performed at once with the term known term solution population. Individual contained in one population is called by the term chromosome. This chromosome is a solution that is still a symbol.

Population is the result of the evolution of chromosomes through literacy called by generation.

There are major components in Genetic Algorithm, that are:

1. Encoding Technique

Encoding techniques includes the gene encoding of chromosomes. Genes are part of the chromosome. 
2. Initialization Procedure

The size of the population depends on what will be solved and the type of genetic operator to be implemented. Once the population size is determined, then an initialization of the chromosomes must be made in that population.

3. Evaluation Function

There are two things to do in evaluating chromosomes, namely the evaluation of the objective function (objective function) and the conversion of objective function into function in that population

4. Selection

This selection aims to provide greater opportunities for the most fit member of the population.

\section{Genetic Operator}

The standard operators commonly used in genetic algorithms are selection, crossover, mutation

6. Parameter Determination

Parameters commonly used in genetic algorithms are population size, crossoverrate, and mutation rate.

The next step was to design a system that was a strategy to solve problems and develop the best solution for the problem. system design also includes how to organize the system into subsystems, and subsystem allocation to hardware components, software, and procedures.

Scheduling is defined as a plan of arrangement of work order and the allocation of resources, both time and facilities for each operation to be completed (Vollman, 2011)

\section{RESULTS AND DISCUSSION}

This stage would be the implementation of the system that was done after the design was completed and then would be implemented in the programming language after the system was analyzed and designed in detail, it went to the implementation stage.

Implementation stage undertaken by the researcher was part of stage to finish arranging the schedule of sport match which would be implemented. Here is how to arrange a schedule with genetic algorithm.

a. Initial population

\begin{tabular}{|l|l|l|l|l|l|l|}
\hline & $\mathrm{X} 1$ & $\mathrm{X} 2$ & $\mathrm{X} 3$ & $\mathrm{X} 4$ & $\mathrm{X} 5$ & $\mathrm{X} 6$ \\
\hline Kromosom 1 & 1 & 1 & 1 & 0 & 0 & 0 \\
\hline Kromosom 2 & 1 & 0 & 1 & 0 & 1 & 0 \\
\hline Kromosom 3 & 0 & 0 & 0 & 1 & 0 & 1 \\
\hline Kromosom 4 & 0 & 0 & 1 & 0 & 1 & 0 \\
\hline Kromosom 5 & 0 & 0 & 0 & 0 & 0 & 1 \\
\hline Kromosom 6 & 0 & 0 & 1 & 1 & 1 & 1 \\
\hline Kromosom 7 & 1 & 1 & 0 & 0 & 0 & 0 \\
\hline Kromosom 8 & 0 & 0 & 1 & 1 & 1 & 0 \\
\hline Kromosom 9 & 0 & 1 & 0 & 0 & 0 & 0 \\
\hline Kromosom 10 & 0 & 0 & 0 & 0 & 1 & 0 \\
\hline Kromosom 11 & 0 & 0 & 0 & 1 & 1 & 1 \\
\hline
\end{tabular}

Explanation:

\begin{tabular}{|c|c|c|}
\hline \multicolumn{2}{|c|}{ Kromosom } & : Competition \\
\hline \multicolumn{2}{|c|}{ Kromosom 1} & : Basket \\
\hline \multicolumn{2}{|c|}{ Kromosom 2} & : Volly \\
\hline \multicolumn{2}{|c|}{ Kromosom 3} & : Table Tennis \\
\hline \multicolumn{2}{|c|}{ Kromosom 4} & : Court Tennis \\
\hline \multicolumn{2}{|c|}{ Kromosom 5} & : Tarung Drajat \\
\hline \multicolumn{2}{|c|}{ Kromosom 6} & : Karate \\
\hline \multicolumn{2}{|c|}{ Kromosom 7} & : Wusu \\
\hline \multicolumn{2}{|c|}{ Kromosom 8} & : Silat \\
\hline \multicolumn{2}{|c|}{ Kromosom 9} & : Swim \\
\hline \multicolumn{2}{|c|}{ Kromosom 10} & :Beautiful Gymnastics \\
\hline \multicolumn{3}{|c|}{ Kromosom 11} \\
\hline \multicolumn{3}{|c|}{ X : Day } \\
\hline X 1 & \multicolumn{2}{|c|}{ : Monday } \\
\hline X 2 & \multicolumn{2}{|c|}{ : Tuesday } \\
\hline X 3 & \multicolumn{2}{|c|}{ : Wednesday } \\
\hline $\mathrm{X} 4$ & \multicolumn{2}{|c|}{ : Thursday } \\
\hline X 6 & \multicolumn{2}{|c|}{ : Friday } \\
\hline
\end{tabular}

b. Calculating Fitness Value

The formula calculates the scheduling weights from the table above:

Kromosom $=\frac{1}{1+\text { number of clashing schedule }}$

Kromosom $1=\frac{1}{1+3}=0,25$

Kromosom $2=\frac{1}{1+3}=0,25$

Kromosom $3=\frac{1}{1+2}=0,33$

Kromosom $4=\frac{1}{1+2}=0,33$

Kromosom $5=\frac{1}{1+0}=1$

Kromosom $6=\frac{1}{1+4}=0,2$

Kromosom $7=\frac{1}{1+2}=0,33$

Kromosom $8=\frac{1}{1+3}=0,25$

Kromosom $9=\frac{1}{1+0}=1$

Kromosom $10=\frac{1}{1+0}=1$

Kromosom $11=\frac{1}{1+3}=0,25$

Total Value : 5,19

c. Counting Probalities 


$$
\text { Prabalitas }=\frac{\text { fitness result } n}{\text { total fitness value }}
$$

Kromosom $1=\frac{0,25}{5,19}=0,048$

Kromosom $2=\frac{0,25}{5,19}=0,048$

Kromosom $3=\frac{0,33}{5,19}=0,063$

Kromosom $4=\frac{0,33}{5,19}=0,063$

Kromosom $5=\frac{1}{5,19}=0,192$

Kromosom $6=\frac{0,2}{5,19}=0,038$

Kromosom $7=\frac{0,038}{5,19}=0,063$

Kromosom $8=\frac{0,25}{5,19}=0,063$

Kromosom $9=\frac{1}{5,19}=0,192$

Kromosom $10=\frac{1}{5,19}=0,192$

Kromosom $11=\frac{0,25}{5,19}=0,048$

d. Selection

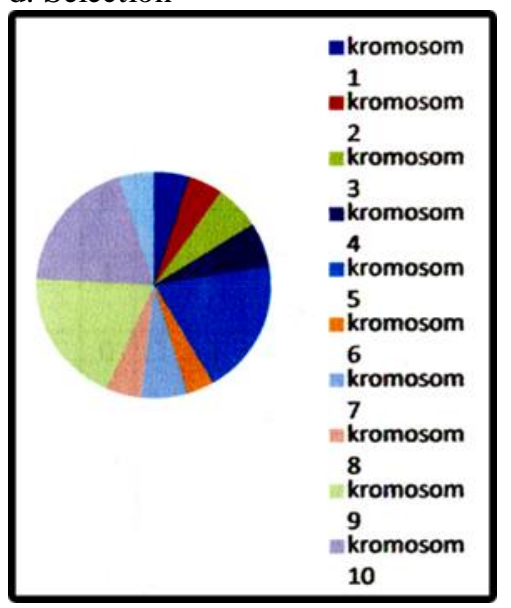

Explanation:

Selection aimed to provide greater opportunities for the most fit members of the population. The higher the fitness value of an individual the more likely to be elected.

e.Crossover

Crossing between chromosomes if the result 0 then the chromosome did not have experience a clashing schedule and if the cross $1+n$ then the chromosome would not be done next crosses.

Kromosom $1><$ Kromosom $2=2$

Kromosom $1><$ Kromosom $3=0$
Kromosom $1><$ Kromosom $4=1$

Kromosom $1><$ Kromosom $5=0$

Kromosom $1><$ Kromosom $6=1$

Kromosom $1><$ Kromosom $7=2$

Kromosom $1><$ Kromosom $8=1$

Kromosom $1><$ Kromosom $9=1$

Kromosom $1><$ Kromosom $10=0$

Kromosom $1><$ Kromosom $11=0$

Kromosom 2 $><$ Kromosom $3=0$

Kromosom 2 $><$ Kromosom $4=2$

Kromosom 2 $><$ Kromosom $5=0$

Kromosom 2 $><$ Kromosom $6=2$

Kromosom 2 $><$ Kromosom $7=1$

Kromosom 2 $><$ Kromosom $8=2$

Kromosom 2 $><$ Kromosom $9=0$

Kromosom 2 $><$ Kromosom $10=1$

Kromosom 2 $><$ Kromosom $11=1$

Kromosom 3 $><$ Kromosom $4=0$

Kromosom 3 $><$ Kromosom $5=1$

Kromosom 3 $><$ Kromosom $6=2$

Kromosom 3 $><$ Kromosom $7=0$

Kromosom 3 $><$ Kromosom $8=1$

Kromosom 3 $><$ Kromosom $9=0$

Kromosom 3 $><$ Kromosom $10=0$

Kromosom 3 $><$ Kromosom $11=2$

Kromosom $4><$ Kromosom $5=0$

Kromosom $4><$ Kromosom $6=2$

Kromosom 4 $><$ Kromosom $7=0$

Kromosom 4 $><$ Kromosom $8=3$

Kromosom 4 $><$ Kromosom 9 $=0$

Kromosom 4 $><$ Kromosom 10 $=1$

Kromosom 4 $><$ Kromosom $11=1$

Kromosom $5><$ Kromosom $6=1$

Kromosom 5 $><$ Kromosom $7=0$

Kromosom 5 $><$ Kromosom $8=0$

Kromosom 5 $><$ Kromosom $9=0$

Kromosom 5 $><$ Kromosom $10=0$

Kromosom 5 $><$ Kromosom $11=1$

Kromosom 6 $><$ Kromosom $7=0$

Kromosom 6 $><$ Kromosom $8=3$

Kromosom 6 $><$ Kromosom $9=0$

Kromosom 6 $><$ Kromosom $10=1$

Kromosom 6 $><$ Kromosom $11=3$

Kromosom 7 $><$ Kromosom $8=0$

Kromosom 7 $><$ Kromosom $9=1$

Kromosom 7 $><$ Kromosom $10=0$

Kromosom 7 $><$ Kromosom $11=0$

Kromosom $8><$ Kromosom $9=0$

Kromosom 8>< Kromosom 10 $=1$

Kromosom $8><$ Kromosom $11=2$

Kromosom 9 $><$ Kromosom $10=0$

Kromosom 9 $><$ Kromosom 11 $=0$

Kromosom $10><$ Kromosom $11=1$

Therefore the result of chromosome crosses which results 0 would be crossed in table form.

\begin{tabular}{|l|l|l|l|l|l|l|}
\hline & X & X & X & X & X & X \\
1 & 2 & 3 & 4 & 5 & 6 \\
\hline $\begin{array}{l}\text { Kromosom1 }>< \\
\text { Kromosom 3 }\end{array}$ & 1 & 1 & 1 & 1 & 0 & 1 \\
\hline
\end{tabular}




\begin{tabular}{|c|c|c|c|c|c|c|}
\hline $\begin{array}{l}\text { Kromosom } 1>< \\
\text { Kromosom } 5\end{array}$ & 1 & 1 & 1 & 0 & 0 & 1 \\
\hline $\begin{array}{l}\text { Kromosom } 1>< \\
\text { Kromosom } 10\end{array}$ & 1 & 1 & 1 & 0 & 1 & 0 \\
\hline $\begin{array}{l}\text { Kromosom } 1>< \\
\text { Kromosom } 11\end{array}$ & 1 & 1 & 1 & 1 & 1 & 1 \\
\hline $\begin{array}{l}\text { Kromosom } 2>< \\
\text { Kromosom } 5\end{array}$ & 1 & 0 & 1 & 1 & 1 & 1 \\
\hline $\begin{array}{l}\text { Kromosom } 2>< \\
\text { Kromosom } 9\end{array}$ & 1 & 1 & 1 & 0 & 1 & 0 \\
\hline $\begin{array}{l}\text { Kromosom 3>< } \\
\text { Kromosom } 4\end{array}$ & 0 & 0 & 1 & 1 & 1 & 1 \\
\hline $\begin{array}{l}\text { Kromosom } 3>< \\
\text { Kromosom } 7\end{array}$ & 1 & 1 & 0 & 1 & 0 & 1 \\
\hline $\begin{array}{l}\text { Kromosom } 3>< \\
\text { Kromosom } 9\end{array}$ & 0 & 1 & 0 & 1 & 0 & 1 \\
\hline $\begin{array}{l}\text { Kromosom } 3>< \\
\text { Kromosom } 10\end{array}$ & 0 & 0 & 0 & 1 & 1 & 1 \\
\hline $\begin{array}{l}\text { Kromosom } 4>< \\
\text { Kromosom } 5\end{array}$ & 0 & 0 & 1 & 0 & 1 & 1 \\
\hline $\begin{array}{l}\text { Kromosom } 4>< \\
\text { Kromosom } 7\end{array}$ & 1 & 1 & 1 & 0 & 1 & 0 \\
\hline $\begin{array}{l}\text { Kromosom } 4>< \\
\text { Kromosom } 9\end{array}$ & 0 & 1 & 1 & 0 & 0 & 1 \\
\hline $\begin{array}{l}\text { Kromosom } 5>< \\
\text { Kromosom } 7\end{array}$ & 1 & 1 & 0 & 0 & 0 & 1 \\
\hline $\begin{array}{l}\text { Kromosom } 5>< \\
\text { Kromosom } 8\end{array}$ & 0 & 0 & 1 & 1 & 1 & 1 \\
\hline $\begin{array}{l}\text { Kromosom } 5>< \\
\text { Kromosom } 9\end{array}$ & 0 & 1 & 0 & 0 & 0 & 1 \\
\hline $\begin{array}{l}\text { Kromosom } 5>< \\
\text { Kromosom } 10\end{array}$ & 0 & 0 & 0 & 0 & 1 & 1 \\
\hline $\begin{array}{l}\text { Kromosom } 6>< \\
\text { Kromosom } 7\end{array}$ & 1 & 1 & 1 & 1 & 1 & 1 \\
\hline $\begin{array}{l}\text { Kromosom } 6>< \\
\text { Kromosom } 9\end{array}$ & 0 & 1 & 1 & 1 & 1 & 1 \\
\hline $\begin{array}{l}\text { Kromosom } 7>< \\
\text { Kromosom } 8 \\
\end{array}$ & 1 & 1 & 1 & 1 & 1 & 1 \\
\hline $\begin{array}{l}\text { Kromosom } 7>< \\
\text { Kromosom } 10\end{array}$ & 1 & 1 & 0 & 0 & 1 & 0 \\
\hline $\begin{array}{l}\text { Kromosom } 7>< \\
\text { Kromosom } 11\end{array}$ & 1 & 1 & 0 & 1 & 1 & 1 \\
\hline $\begin{array}{l}\text { Kromosom } 8>< \\
\text { Kromosom } 9\end{array}$ & 0 & 1 & 1 & 1 & 1 & 0 \\
\hline $\begin{array}{l}\text { Kromosom } 9>< \\
\text { Kromosom } 10\end{array}$ & 0 & 1 & 0 & 0 & 1 & 0 \\
\hline $\begin{array}{l}\text { Kromosom } 9>< \\
\text { Kromosom } 11\end{array}$ & 0 & 1 & 0 & 1 & 1 & 1 \\
\hline
\end{tabular}

\section{RESULTS AND ANALYSIS}

From the results and discussion above, it can be concluded as follows :

1. Using the schedule of this activity can facilitate the board in the preparation of sports activities schedule and reduce the occurrence of errors in making a schedule.
2. Researchers hope more and more preparation schedule of other activities on campus that many experience clashing by using the method of genetic algorithm.

\section{BIBLIOGRAPHY}

[1]. Arhami. M. (2011). Algoritma Genetika, Suatu Alternatif Penyelesaian permasalahan Searching. Pens-ITS Surabaya.

[2]. Vollman, T.E. (2011). Manufacturing Planning and Control System For Suplly Chain Management, McGraw-Hill. 